\title{
СЕЛЬСКО-ГОРОДСКОЙ КОНТИНУУМ: СУДЬБА ПРЕДСТАВЛЕНИЯ И ЕГО СВЯЗЬ С ПРОСТРАНСТВЕННОЙ МОБИЛЬНОСТЬЮ НАСЕЛЕНИЯ
}

\author{
АНДРЕЙ ТРЕЙВИШ1, *
}

\begin{abstract}
Статья посвящена эволющии, схемам и сферам приложения идеи сельско-городского континуума, разнообразию его пространственных и отчасти исторических форм, их типам и свойствам. Эту идею часто определяют от противного, противопоставляя ее антиномии города и села, их резкому разделу, территориальному и социальному. Автору представляется, что сельско-городской континуум (континуумы) служит синонимом расселения, понимаемого как сплошное поле, которое можно исследовать в разном масштабе, при разной пропоричи города и села. Из обзора графических схем вытекает вывод, что разные версии комплементарны, отражая эволюционную, полимасштабную и градуальную природу континуума. Анализ избранного западного и российского опыта завершен попыткой типизации континуумов по основным регионам России. Сложность $u$ неоднородность нарастают от локального полусельского типа $\kappa$ межрегиональному мегагородскому с интерференцией разных континуальных полей. Мобильность населения 6 континуумах иллюстрируют примерные расчеты ее параметров по Москве и России. Эта мобильность делает расселение не только континуальным, но и пульсирующим. В заключении кратко изложены проблемы управления, которому по ряду причин трудно усвоить саму идею континуума.
\end{abstract}

Ключевые слова: сельско-городской, локальный (народно-городской) континуум, расселение, образ жизни, пространственная мобильность, агломеращия, мегалополис (мегарегион).

\section{ВВЕДЕНИЕ}

Социальные явления, как известно, существуют во времени и пространстве. Вся сопряженная философия автору статьи не по зубам, но разговор о сельско-городском континууме ему хочется начать с понимания пространства в гуманитарных науках. Оно варьируется от условно-метафорического до конкретно-географического.

\footnotetext{
${ }^{1}$ ИНСТИТУТ ГЕОГРАФИИ РОССИЙСКОЙ АКАДЕМИИ НАУК (РОССИЯ).

*E-mail: trene12@yandex.ru

СТАТЬЯ ПОСТУПИЛА В РЕДАКЦИЮ В НОЯБРЕ 2015 Г.

СТАТЬЯ ПОДГОТОВЛЕНА ПРИ ПОДДЕРЖКЕ ГРАНТА РОССИЙСКОГО НАУЧНОГО ФОНДА (ПРОЕКТ № 14-18-ООО83 «ГЕОГРАФИЯ ВОЗВРАТНОЙ МОБИЛЬНОСТИ НАСЕЛЕНИЯ В СЕЛЬСКО-ГОРОДСКОМ КОНТИНУУМЕ») В ИНСТИТУТЕ ГЕОГРАФИИ РАН.
} 
Первое характерно для «социальных пространств» Э. Дюркгейма, М. Фуко, Т. Парсонса, П. Бурдье. В их многомерных пространствах практик, процессов, отношений земное «физическое» измерение второстепенно или отсутствует. Мотивы поясняет А.Ф. Филиппов [2008]. Очевидность того факта, что люди действуют в пространстве и времени, он считает обманчивой. Если в пространстве находится действующий человек, то отсюда еще не следует, что в пространстве находится его действие. Аргументы часто облечены в форму вопросов. Что мы скажем о театральной труппе, которая не имеет постоянной сцены, а кочует из театра в театр, из города в город? Как быть с семьей, члены которой в силу обстоятельств оказались вдалеке друг от друга, но не прерывают отношений? Вывод: пространство не является всеобщей формой совершения социальных событий, и мэтры понимали его не буквально, а иносказательно.

Другие ученые погружали жизнь человека и общества в далекое от аллегорий земное пространство-время. К ним можно отнести О. Конта, Г. Спенсера, М. Вебера, Г. Зиммеля, классиков марксизма, не говоря о геодетерминистах Ж. Бодене, И. Гердере, Ш. Монтескье и современных специалистах по социально-экономической географии, региональной экономике, социологии, демографии. Они скажут, что специфику кочующей труппы и разделенной семьи как институтов создают именно пространственно-временные параметры. Впрочем, эти специалисты могут трактовать пространство двояко. Как среду развития общества, независимую переменную Эвклида и Ньютона, особенно если это природный слой геосферы, существовавший до людей и способный обойтись без них. Или как особое социальное геопространство, формируемое ходом и результатами развития, что ближе к пространству Декарта и Лейбница.

Конкретно-научный дискурс обычно обходит эти тонкости, вникая зато в другие. Так, сети расселения людей на той или иной территории допустимо считать средой их жизни, протекания демографических и прочих процессов либо плодом последних. Это не снимает вопросов о том, каковы движущие силы, тренды и формы расселения, образует ли оно системы, некие сплошные поля или состоит из дискретных ячеек, а также о типах и масштабах занятых последними ареалов.

Идея сельско-городского континуума по определению отстаивает континуальный подход к расселению в противовес дискретному. Диалектика этих качеств важна не только для философии или, скажем, физики (квантово-волновой дуализм и др.), но и для наук социальных, и для общества как такового. При неделимости своей элементарной частицы (человека) оно может пониматься как всемирное ноосферное поле или как набор условно автономных сообществ. Впрочем, крайние позиции обычно ведут в тупик.

Когда и где возникла мысль о сельско-городском континууме (кратко СГК), как она менялась со временем, где и для чего применима? На эти вопросы автор пытается дать в статье хотя бы приблизительные ответы.

\section{ГЕНЕЗИС, ЭВОЛЮЦИЯ И СУТЬ ИДЕИ СГК}

Во взглядах на город и деревню долго преобладал дискретно-дихотомический и контрарный подход. Кстати, контрарность как логическое отношение требует наличия 
общего гиперонима, объединяющего понятия. Видимо, в данном случае это человеческое поселение, населенное место или местность. Проблема их разграничения знакома археологам: раскоп не всегда определим как городище, селище, участок поля или огорода. Город веками противопоставляли деревне и в то же время выдвигали идеи устранения противоположности между ними, что в СССР вылилось в лозунг «стирания граней». Но эти грани, в том числе нормативные, не исчезали, а «смычка» шла универсальными путями урбанизации, подчинения деревни городу, физического поглощения им или переходной зоной пригородов. Сельские жители вовлекались в его трудовую, культурно-бытовую орбиту, а горожан тянуло «к природе»: туризму, аграрно-рекреационным (садово-дачным) владениям и занятиям. В общем, крепло единение города и села, отражаемое понятием СГК и облегчаемое ростом пространственной мобильности людей.

Исторический тренд этого роста американский географ У. Зелински более 40 лет назад положил в основу гипотезы миграционного (мобильного) перехода [Zelinsky 1971]. Вдохновленный набиравшей вес теорией демографического перехода, раскрывшей законы эволюции естественного воспроизводства населения, он искал закономерные стадии его механического движения, модернизации пространственного поведения. Современный английский автор Дж. Урри [2012] уже занят разработкой «социологии мобильности» для XXI века. Но о мобильности позже.

Временем оформления европейского урбанизма и антиурбанизма считают середину XIX века [Горнова 2011], хотя восторг пополам с ужасом от деревни и, еще чаще, от города куда старше. Вспомним о теории и практике средневекового отшельничества, о социальном утопизме, учении физиократов (Ф. Кенэ, А. Тюрго) и руссоистских идиллиях XVIII века. Критики и яркие апологеты города (Р. Флорида, Э. Глейзер) активны и сейчас. Антиномию города и деревни современная наука часто трактует как вариант более общей центропериферийной.

На рубеже XX века западная урбанизация, казалось, довела противоречия до предела. Первым их пытался устранить британский теоретик градостроительства Э. Ховард. Его схема трех магнитов из книг 1898 и 1902 г. [Нoward 1902] вкратце такова. Город притягивает своими возможностями, но дорог, тесен, грязен и контрастен. У села нет этих пороков, но там мало денег, занятий, общения и развлечений. Выход - «градодеревня», она же город-сад, где совмещены «магнитические» плюсы. На практике все это вылилось в новые города-спутники европейских столиц и в безудержное расползание американских пригородов с их моторизованным населением. Ховарда часто считают утопистом, но его можно назвать и прямым предтечей идеи СГК.

Она возникла на рубеже 1930-х годов у чикагских социологов и антропологов. П.А. Сорокин и К. Циммерман, исходя из идеальных города и деревни и гаммы переходов между ними (в любой общине есть признаки обоих) по числу, плотности и мобильности жителей, их отношениям, занятиям и т.д., вплотную подошли к идее континуума [Sorokin, Zimmerman 1929]. Р. Редфилд нашел в одной общине - Тепостлан в 30 милях к югу от Мехико - пример народно-городского (folk-urban) континуума, где традиционный уклад переплетался с промышленно-городским [Redfield 1930]. Впоследствии за явлением всетаки закрепился термин СГК (rural-urban continuum). 
Обычно СГК определяют от противного: как неприятие полярности города и села, их резкого территориального и социального раздела. Эти два «нераздела» дополняют друг друга так же, как континуальные и дискретные построения. На условную континуальность может претендовать типология, а ее объекты - оставаться пространственно дискретными. Или наоборот, ведь эти категории дополнительны. По словам В.В. Пациорковского [2010: 29], сама непрерывность СГК, данная нам в конкретном пространстве и времени, воспринимается как конечное, прерывное отношение. Отсюда вообще-то должно вытекать признание множественности СГК, различающихся по пространственным и населенческим масштабам, строению, характеру связей.

Судьба идеи (думается, она не стала теорией: идеальный объект, один из признаков теории, налицо, но его свойства довольно расплывчаты) сложилась неодинаково в разных отраслях знания. Социологи и культурологи в пору своего увлечения СГК сопрягали его с общинным Gemeinschaft и общественным Gesellschaft (по Ф. Теннису) сплочением, стратификацией, модерном и традицией, образом жизни, вертикальной и горизонтальной мобильностью. С чем только не сопрягали!

В середине XX века идею уже критиковали. В том числе за ее неуместность на фоне кризиса сельских общин и фермерства под натиском промышленно-городского бизнеса и технологий [Miner 1952] или на том основании, что ни она, ни различия города и села не важны, если это одна и та же цивилизация [Dewey 1960]. K XXI веку макросоциологи охладели к идее СГК из-за стирания сельско-городских контрастов: в «мировой деревне» выросли города-гиганты, а в «мировом городе» не стало традиционной деревни.

Вряд ли это верно для всей планеты, где доля горожан едва превысила $1 / 2$. А если верно, то скорее повышает роль СГК-подхода к сложным, интегральным формам расселения, когда грани порой и впрямь так размыты, что у любого пункта есть признаки антипода. Поэтому СГК интересен географам, планировщикам и всем тем, кто изучает расселение. Здесь у него свои идейные спутники, такие как эволюционные и центропериферийные модели. Но СГК - не стадия и не таксон расселения, скорее это синоним расселения в целом, понимаемого как непрерывное поле в разных масштабах, с разной долей города и села. СГК не устраняет их роли в жизни людей и разделении труда, причем село, главный агент агрофеодального расселения, становится затем ведомым

городом. В таком виде это не столько идеально-проектный конструкт, сколько форма представления реальности, что не отменяет спроса на ее модели и схемы.

\section{АБСТРАКТНЫЕ И КОНКРЕТНЫЕ МОДЕЛИ (СХЕМЫ) СГК}

Простейшая общая схема [World Development... 2009: 51] сводит дихотомию города и села к пунсону города на сельском фоне. «Более реалистичный» СГК с пунктами-селениями на таком же фоне рисует городской мегарегион (мегалополис), а в нем - отдельные города и метрополитенский (агломерационный) ареал. Вообще-то такой регион обычно включает не одну агломерацию и не бывает резко отделен от сельского фона, который на схеме почти не дифференцирован. От «просто города» по дихотомической версии его отличает наличие внутренней структуры. 
Богаче деталями схема английского географа П. Клоука [Cloke 1979] с признаками эволюции пригородных селений по зонам транспортной доступности центра. Ближайшие к нему в ходе субурбанизации выросли в город-спутник или сохранили старые ядра, но обросли городской застройкой. В одном месте за линией 1,5-часовой изохроны дома стали вторыми, дачными. Но вне агломерации здесь тоже нет малых городов - центров сельской глубинки, локальных «народно-городских» континуумов Р. Редфилда.

Они издревле покрывали своей сетью Ойкумену. Скромный масштаб и несложный состав не сводили их к паре центр - периферия хотя бы из-за «пульсации» населения по сезонам года, нуждам прокорма и обороны. Роль города мог играть сельский ярмарочный или культовый центр, караван-сарай, замок сеньора, который мог затем стать городом дефакто и де-юре. У агломераций и других сгустков современного населения тоже были предтечи: сельские зоны поливного земледелия с сетью городов и их эмбрионов. Они поныне завышают долю горожан по сравнению с официальной статистической при оценке не по статусу пунктов, а по числу, плотности жителей и близости к большим центрам в ряде тропических стран. Но занижают в таких странах, как Россия, где локальные СГК рассеяны, малы и не отвечают универсальным меркам городского населения, хотя формально оно там есть [World Development... 2009; Нефедова 2013]. В мощные урбанистические образования входят сельские и дачные ареалы, что позволяет совмещать и чередовать два образа жизни. Так, Центрально-Русский мегалополис в 3-4 раза обширнее Московского региона, поскольку захватывает части других. Драйверы его развития городские, а вот по площади тут больше «села», чем города [Махрова и др. 2012].

Типовые сельско-городские связи кратко приведены в таблице 1 по схеме К. Линча [Lynch 2005] для третьего мира. Важно, что в СГК их активизирует сближение и тесное общение полюсов. При глобализации село может поставлять товары и услуги, работников и студентов не в местный, а в более дальний и крупный центр, получая взамен импульсы развития. Но не все связи строятся по принципу дальнодействия, многие, как и встарь, ориентированы на ближайшее соседство.

\section{Таблица 1. Основные сельско-городские связи по К. Линчу}

\begin{tabular}{lcc}
\hline Тип связей & Сельская местность - городу & Город - сельской местности \\
\hline Ресурсно-экологические & Вода, энергия и т.п. & Загрязнение \\
Человеческие & Трудовая, учебная миграция & Возвратная/пенсионная миграция \\
Продовольственные & Свежие продукты питания & Переработанная продукция \\
Денежные & Сбережения & Инвестиции \\
Идеологические & Крестьянизация, рурализация & СМИ, культурная урбанизация \\
\hline
\end{tabular}

Схемы СГК можно связать с эволюционными схемами расселения. Первую, как известно, выдвинул Дж. Джиббс [Gibbs 1963], предложив пять универсальных стадий с чередующимся ростом и упадком населенных мест разного типоразмера. Их география не уточнялась. У Ж.А. Зайончковской [1991] стадий меньше, ведут они от давних эпох, когда малые центры вписывались в сельские ареалы, эксплуатируя и опекая их, укрывая от врагов жителей локальных СГК, к стадии относительной автономии города, в том числе географической. Затем село жмется к городам-лидерам. Наконец, прореженная руральная «ткань» заново интегрируется с урбанистической (рисунок 1). 

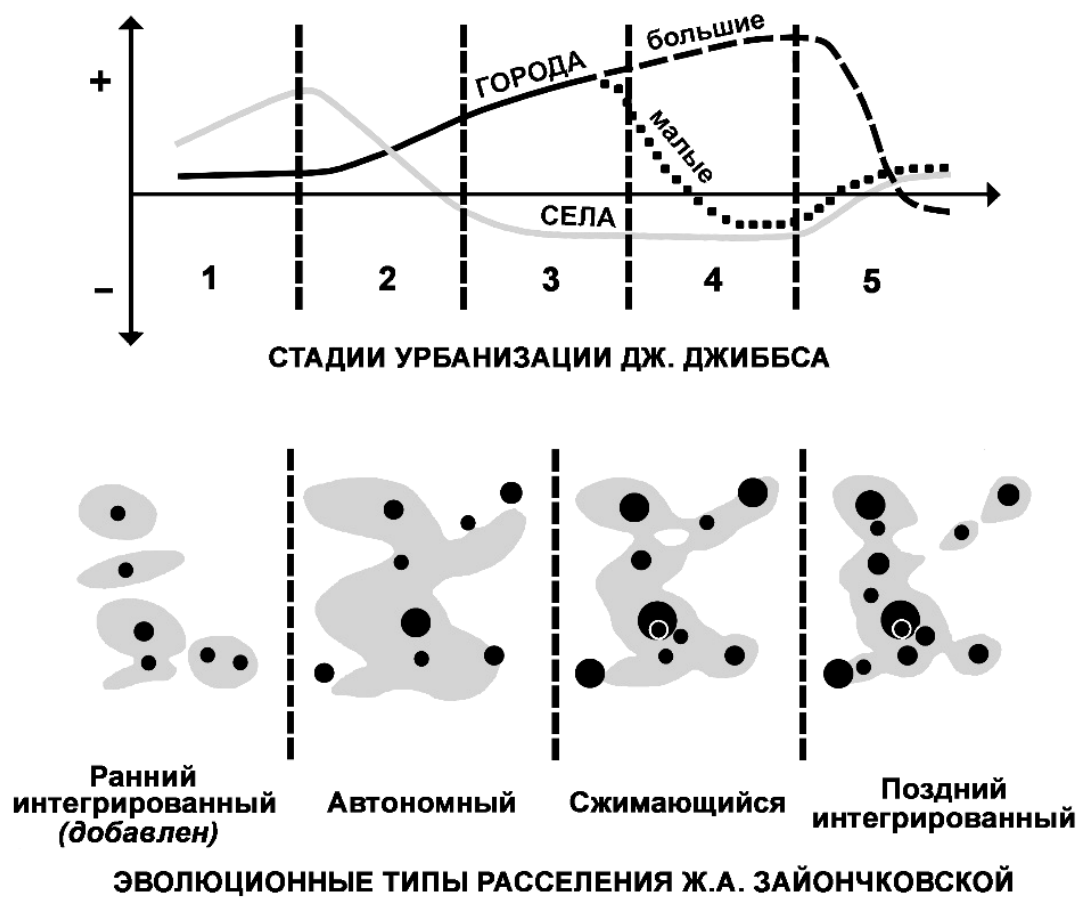

Рисунок 1. Схемы эволюции расселения Дж. Джиббса и Ж.А. Зайончковской

Примечание: Схема Ж.А. Зайончковской дана в графической интерпретации автора статьи.

Белые поля вне серых ареалов сельского расселения - это пустынные природные территории. Их относят к сельским как «все, что не город», но для районов и стран это подходит тем хуже, чем они крупнее и малолюднее. Сам корень «сел» предполагает население, и скорее оседлое. Континуальность социального пространства благодаря мобильности людей касается любых территорий, в том числе неосвоенных, а стабильные поселения (признак обжитой территории) есть не везде. В урбанизированном же СГК не безлюдны и природные ландшафты.

Модель СГК с эволюционным прицелом есть в материалах по миграции Продовольственной и сельскохозяйственной организации ООН (ФАО) [The urban-rural continuum... 1998]. Комментарий гласит, что кривые со временем меняются: от А к В и от В к С (рисунок 2). Хотя пространство между городом и деревней условно, сельская ось похожа на географическую, как при трехмерном изображении версии В с городом-горой и волнистым сельским плато, типичной, как сказано, для развивающихся стран. Широкое «предгорье» пригородов можно принять и за признак перехода к стадии С. Тогда С - это такая мегаполизация, которая вобрала в свой континуум все население страны, укоротила сельскую ось и с ней протяженность обжитого пространства. 


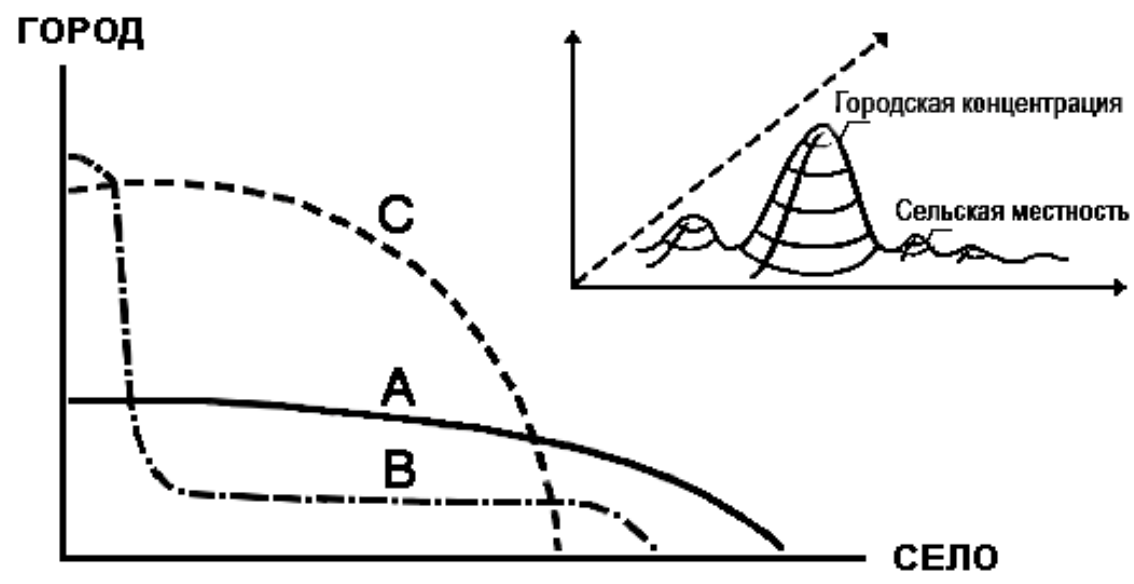

Рисунок 2. Двухмерное представление сельско-городского континуума

\begin{abstract}
Примечания: A - страна с преобладанием сельского населения; $B$ - страна с одним «приматным» крупногородским ичентром; $C$ - «сбалансированный» вариант. Справа вверху - трехмерное представление варианта $B$.
\end{abstract}

Источник: версия ФАО [The urban-rural continuит... 1998].

Разные абстрактные схемы СГК дополняют друг друга, отражая развитие идеи, ее географическую разномасштабность в диапазоне от глобального уровня до локального и «градуальную» природу. Но строго непрерывной графику этих схем не назовешь: в той или иной мере они дискретизируют картину.

К моделям СГК для конкретных территорий относится модель потенциала поля расселения. Популярная у географов в годы «количественной революции», она не исчезла и теперь. Примером служат поля показателей мирового развития [Тикунов 2009: гл. 3]. Континуальная логика ведет к «покрытию» ими даже морских акваторий. Безлюдность максимальна на юго-востоке Тихого океана как антиполюсе массы азиатского населения, а «внехозяйственность» (в поле валового продукта) - в Антарктиде, антиподе северных ядер мировой экономики. Условность физикалистской модели, ее параметры, интерпретация и т.д. вызывали споры. В то же время этот образ СГК зависит от типа «масс», расстояний и потенциальных взаимодействий.

Конкретный опыт «построения» СГК есть в Америке, на родине идеи, и не только там, но часто без ссылки на нее. В отличие от градиентов (векторов) сельско-городских полей в предыдущей модели, здесь на первый план выходят дискретные единицы-районы, принципы их классификации, а для количественных оценок и карт - градации на шкале переходов. Разные ведомства предлагают группировки округов-графств США по степени их урбанизированности, что диктует деление на метрополитенские (или агломерационные) и внеагломерационные ареалы ${ }^{1}$. В двух схемах 2013 г. акцент делался на разные части СГК

\footnotetext{
1 Метрополитенские статистические ареалы (МСА) группируют округа-графства «ядерным» методом. К ядрам с населением от 50 тыс. человек добавляют смежные округа при известном уровне плотности горожан и их трудовых поездок в ядро. Бюро переписей США с 2000 г. выделяет также микрополитенские ареалы при ядрах с 10-50 тыс. человек. К 2015 г. их было более 540, а МСА - 388. При скромных требованиях к ядрам MCA имеют в среднем 700 тыс. человек и редко меньше 100 тыс. Ядру микроареала достаточно 10 тыс.
} 
[NCHS Urban-Rural... 2013; Rural-Urban Continuum... 2013]. На одной детализированы метрополитенские статистические ареалы (MCA), а вне их выделены микрополитенские ареалы и «безъядерная» сельская зона. На другой «коды» округов дифференцируют их по месту в СГК полнее. Чем шкала подробнее, тем картина «континуальнее» и пестрее, хотя главные свойства те же. «Городской мир» доминирует в США по берегам Атлантики, в Калифорнии и во внутренних очагах урбанизации. Нужно, правда, учесть, что иные городские округа запада страны, размером с целые области России, тянутся миля за милей по пустыне. «Безъядерность» руральных зон Центральных равнин и Скалистых гор не означает отсутствия там локальных СГК. Просто они и их ядра (до 10 тыс. человек) скромнее.

В России сложились свои традиции континуального анализа расселения. Не имея статистики маятниковых миграций, градоведы определяли возможности этих поездок по изохронам транспортной доступности центров для выделения агломерационных и других зон. Замена американского критерия смежности муниципальных единиц дистанционнотранспортным отчасти связана со слабостью дорожной сети, что повышает ее значение для связей. Таковы, например, многолетние разработки А.М. Лола [2005]. Но они трудоемки, и мониторинг ситуации трудно представить без геоинформационных технологий. Заокеанские методы в этом смысле проще.

Микроареалы локальных СГК у нас выделяли редко, в немногих регионах и чаще в Европейской России, особенно Центральной [Нефедова 2003; Ткаченко, Фомкина 2012; 2014; Гунько, Глезер 2015]. Эти разработки похожи на американские, хотя наряду с учетом соседства муниципальных районов используют оценки транспортного положения и концептуально опираются не столько на СГК, сколько на модель центр-периферия. Фактически они все же следуют логике континуума, что видно по обилию переходных категорий, таких как полугород, полупригород, полуглубинка.

К идеологии СГК примыкают типологии городов по наличию у них городских и сельских признаков. Один из них - обеспеченность жилья канализацией или ее отсутствие: выгребная яма на дворе служит приметой застройки сельского типа, «частного сектора» [Нефедова 2013]. Коммунальная статистика позволила оценить долю городских земель под такой застройкой. По ней выделены 75 «супергородов» и 222 типичных или «просто города»: большинство региональных центров и еще 130 без этого статуса. В немногих «собственно городах» живут 60\% статистических горожан, а сотни «не совсем городов» и «совсем не городов» невелики.

Попробуем теперь типизировать СГК на уровне регионов всей России, опираясь на схему ФАО (см. рисунок 2), развернутую за счет смешанно-переходных типов. Типы разнятся, прежде всего, по территориально-урбанистистической структуре: размерам и плотности городских (и сельских) поселений, наличию надгородских форм. Сводным показателем служил так называемый интегральный коэффициент урбанизированности [Полян 2014: 263-281]. При уточнении принадлежности регионов к тому или иному типу учитывались порознь и его компоненты: распределение городских пунктов по категориям 
людности, их доля в населении, плотность горожан и сельских жителей, а также присутствие в регионе крупных агломераций или надагломерационных образований (мегарегионов) и степень охвата ими его территории. Вместо обозначений $\mathrm{A}, \mathrm{B}, \mathrm{C}$ из схемы ФАО введены более содержательные: сельско-мелкогородской $(\mathrm{CM})$, городской $(\Gamma)$ и мегагородской (МГ) типы. В тип СМ включены как сельские обжитые, так и необжитые ареалы, но зато добавлены еще пять типов, особенно «на подступах» к мегагородскому. Регионы вообще-то - не лучшие ячейки для решаемой задачи, так что речь идет скорее о преобладании и сочетании разных типов СГК в их границах.

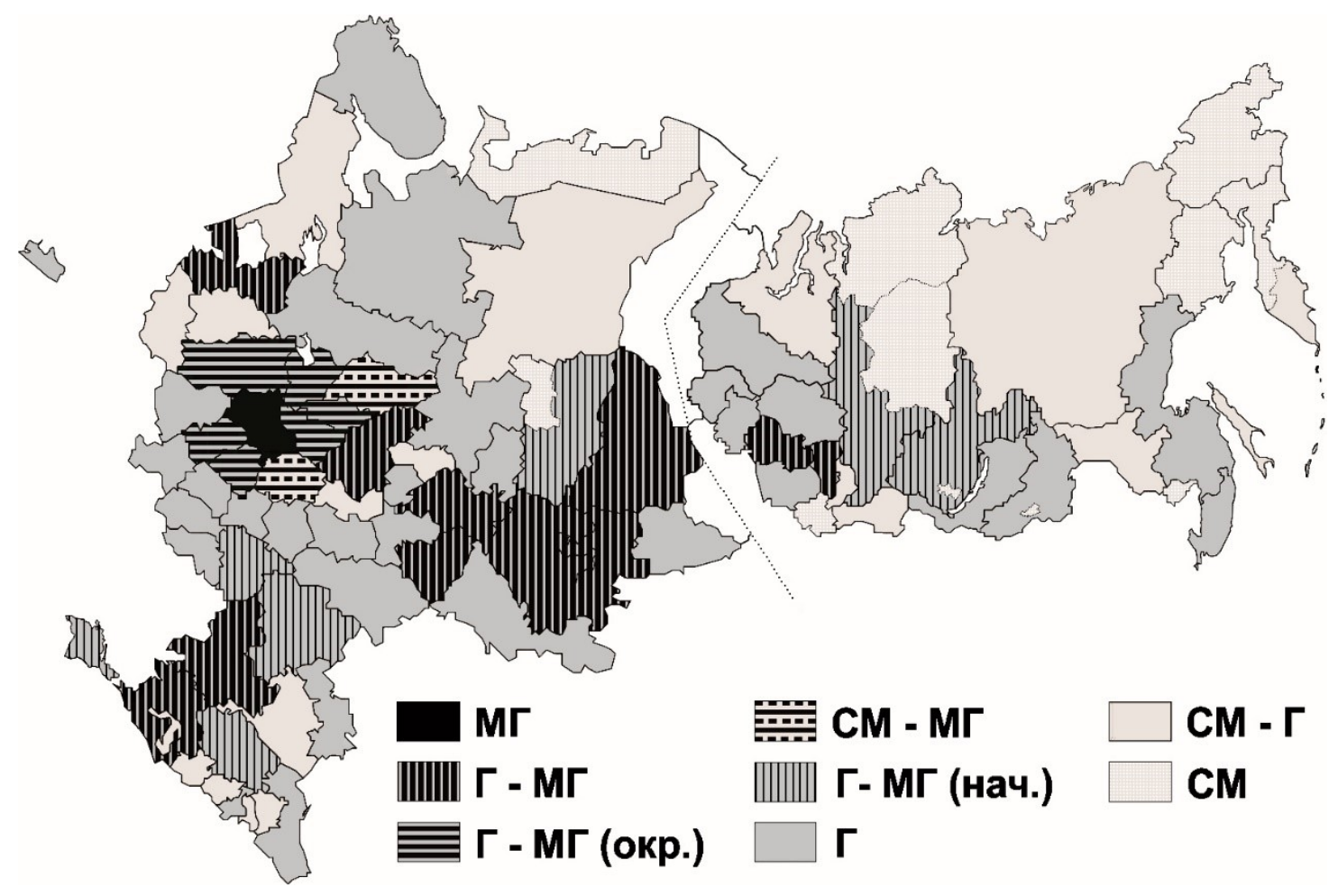

Рисунок 3. Типы сельско-городских континуумов в регионах России

\begin{abstract}
Примечания: Регионы России, включая автономные округа, потерявщие статус субъектов РФ в 2000-х гг., без северных островов; города федерального значения объединены с окружаюшими регионами. МГ-мегагородской; Г- МГ- промежуточный между городским и мегагородским; $Г$ - МГ (окр.) - то же по окраине Центрально-Русского мегалополиса, СМ - МГ-промежуточный между сельско-мелкогородским и мегагородским; Г - МГ (нач.) - с начальными признаками перехода к мегагородскому; $\Gamma$-городской с крупным центром; $C M-\Gamma$-промежуточный между сельскомелкогородским и городским (с большим центром); СМ - сельско-мелкогородской.
\end{abstract}

Мегарегион выделен один - Московский, ядро Центрально-Русского мегалополиса (рисунок 3). За счет его окраин 6 смежных областей отнесены к особому типу (иначе они были бы просто городскими). Еще две области, Рязанская и Костромская, чьи эксцентричные столицы входят в тот же мегалополис, дают резкий переход к нему от руральной среды с отсутствием даже среднего (50-тысячного) города. Смесь признаков двух базовых типов найдена еще в 11 регионах с мощными агломерациями и «лестницей» малых, средних, больших, а то и крупных центров: от 250 тыс. человек. Горожан там обычно более 2 млн, и на селе жителей немало. Те же свойства в меньших масштабах дают 
тип с признаками начальной мегаурбанизации, географически примыкающий к ареалам Г МГ.

Тип с симптомами вырастания из крупногородской стадии представлен шире всего: более 30 регионов, особенно в главной полосе расселения. Вне этого типа оставил свою область, где остальные города малы, только один миллионник - Омск. Признаком перехода к городскому типу от сельско-мелкогородского служит центр, не доросший до 100 тыс. жителей. Исключения - Якутия, Карелия - вошли в этот тип из-за сильной разреженности социального пространства с доминированием лесных, сельских и полугородских ареалов.

Регионы типа СМ, обычно северные и восточные, лишены больших городов и состоят из локальных континуумов и «безъядерных» зон.

Неоднородность регионов как вместилищ СГК явно нарастает от последнего типа к первому. Локальным центрам часто недостает потенциала, чтобы создать свое поле взаимодействий. Для сложных урбанизированных структур с высокой плотностью населения, деятельности, инфраструктуры характерно сочетание СГК разного масштаба, хотя малые формы «в тени» города-гиганта нередко подавлены, если не поглощены им вместе с бывшими рощами, полями, лугами, фермами, дачами.

Демографические различия полюсов расселения со временем меняются. Когда-то сельское население могло расти быстрее городского благодаря большей рождаемости, меньшей скученности и антисанитарии, зависимости от внешнего снабжения. Большой город, пионер демографической и прочей модернизации, первым ощущал ее результаты в виде нуклеарной семьи, суженного воспроизводства «коренных» горожан и т.д. ${ }^{2}$. Зато этот фокус инноваций, коммуникаций, элит и капиталов, промоутер и витрина социальной мобильности служит также полюсом мобильности пространственной. И его окружение (весь СГК) при прочих равных условиях меньше страдает от таких типовых болезней, как монопрофильность, миграционный отток, депопуляция и т.д., чем представители той же ступени поселенческой иерархии, оказавшиеся вдали от гиганта. Здесь тоже помогает мобильность, сама широта выбора ее видов и форм.

\section{ПРОСТРАНСТВЕННАЯ МОБИЛЬНОСТЬ НАСЕЛЕНИЯ И СГК}

Пространственная мобильность не тождественна горизонтальной социальной: ее может сопровождать вертикальный подъем или спуск по социальным лестницам, а горизонтальная смена веры, семьи, работы может состояться на одном месте. Не вникая в терминологические споры о миграции и мобильности, отнесем к последней все межселенные перемещения: безвозвратные переселенческие и возвратные временные, более массовые. Так, из страны в страну за год переселяются примерно 250 млн человек, а поездок интуристов Всемирная туристская организация ООН (ЮНВТО) фиксирует более 1

\footnotetext{
${ }^{2}$ В начале демографического перехода его лидерство еще нагляднее. По оценке Б.Н. Миронова [1999: т. 1: 236], в XIX веке город в России обгонял деревню по изживанию архаических семейных форм лет на 50, то есть на пару поколений. Затем разрыв сокращался, нижние этажи расселения опережали верхние по остроте проблем, вызванных демографическими процессами, не получая миграционной компенсации извне. 
млрд. Иностранцы-гастарбайтеры, курсируя между родиной и страной-работодателем, добавят не менее полумиллиарда поездок. Внутри стран учет мобильности неполон, но обычно она еще активнее. Сюда входят поездки с деловыми (трудовыми), семейнобытовыми, туристско-рекреационными и другими целями, разные по частоте и дистанции.

Последние взаимосвязаны: частота статистически убывает с расстоянием. Мы чаще движемся по своему дому, чем по городу, селу и тем более между ними. Отсюда связь мобильности с СГК. Вообще-то до двух миллиардов землян считаются иммобильными, не покидающими своих микроареалов, малых родин, но внутри локальных СГК и эти люди движутся. Легко подсчитать: делая в день всего 10 км, за 30 лет «накрутишь» 110 тыс. км пути, или 2,7 длины экватора. Поэтому и в глобально-мобильном мире мобильность выше в местах скопления ее носителей. Даже слабый местный центр привлекает комьютеров, покупателей, сельских гостей. В мегагородских СГК движутся миллионы, а межселенных поездок за год совершаются десятки и сотни миллионов.

Вот условный расчет для Москвы по статистике за 2012-13 гг. [Численность и миграции... 2013; Обследование населения... 2013; Население России... 2015] с коррекцией оценками разных экспертов и рядом допущений. Безвозвратных мигрантов в город и из него регистрируется за год 0,3 млн, это и будет число их условно однократных переездов. Массу комьютеров (маятниковых мигрантов) примем за 1 млн, а частоту их поездок в одну сторону - за 230 (без уикендов, праздников, отпусков и дней болезни). Участники более дальних и менее частых трудовых миграций, т.е. новые российские отходники и гастарбайтеры из-за рубежа, грубо оценены в 1,5 млн на каждую группу. Дачников-москвичей, включая садоводов, арендаторов чужих дач, ездящих в отпуск к родне и в свой сельский дом, не менее 5 млн. ${ }^{3}$ Средняя частота их поездок - 25 (на 135 нерабочих дней) - немного выше, чем у отходников. По минимуму оценены прочие участники передвижений (таблица 2).

Таблица 2. Ориентировочные параметры ежегодной мобильности населения в Москве

\begin{tabular}{|c|c|c|c|c|c|}
\hline Категория & $\begin{array}{c}\text { Участники, } \\
\text { млн }\end{array}$ & $\begin{array}{c}\text { Среднее число } \\
\text { поездок* }\end{array}$ & $\begin{array}{c}\text { Всего } \\
\text { поездок, млн }\end{array}$ & $\begin{array}{c}\text { Средняя } \\
\text { дистанция } \\
\text { поездки, км* }\end{array}$ & $\begin{array}{c}\text { Суммарно, } \\
\text { тыс. км** }\end{array}$ \\
\hline Мигранты на ПМЖ & 0,3 & 1 & 0,3 & 1900 & 1,9 \\
\hline Комьютеры & 1,0 & 230 & 230 & 55 & 25,3 \\
\hline Отходники & 1,5 & 20 & 30 & 900 & 36,0 \\
\hline Гастарбайтеры & 1,5 & 3 & 4,5 & 2500 & 15,0 \\
\hline Дачники & 5 & 25 & 125 & 90 & 4,5 \\
\hline Прочие *** & 5 & 4 & 20 & 500 & 4,0 \\
\hline Итого & 14,3 & - & 410 & - & 86,7 \\
\hline
\end{tabular}

В сумме это 14 млн человек, больше, чем число постоянных жителей Москвы из-за ее временного населения и отчасти из-за двойного счета, особенно в графе «прочие». По

\footnotetext{
${ }^{3}$ Треть москвичей, вывозящих на лето свои семьи за город, пополняют ряды комьютеров из области в столицу. В другие сезоны года их доля сильно сокращается [Махрова, Кириллов 2015].
} 
числу поездок лидируют ежедневные комьютеры и дачники. Итог составил 410 млн - как если бы за год Москву посетили все жители США и Германии, а если добавить Подмосковье, то и Японии (правда, поездки москвичей в область дублируют те, что уже вошли в расчеты по столице). Из них не менее 250 млн поглощает мегаконтинуум, объединяющий Московский регион с окрестными, даже без учета тех поездок жителей окраин большого СГК, что совершаются в обход его ядра. Оценив средние расстояния поездок по категориям, можно рассчитать годовой «пробег» пассажира, максимальный при временных трудовых миграциях. Суммарный километраж за год превосходит двойной оборот вокруг света по экватору. Ручаться здесь можно разве что за порядок цифр, но в любом случае они внушительны.

Столь массовая мобильность и жизнь многих ее акторов на два, а то и на три дома порождают особый феномен в расселении - его пространственно-временную пульсацию. В пространстве она ярко выражена именно в СГК, а во времени определяется ритмами жизнедеятельности (от суточных до многолетних). Оценка по разным материалам средней зимней и летней людности крайних этажей упрощенной иерархии поселений - крупных городов и любых малых пунктов, включая сельские (до 50 тыс. человек), дает «зазор» между сезонами в 7-8 млн человек. Его хватает, чтобы перевернуть картину: зимой больше людей оказывается на верхнем этаже, а летом - на нижнем. Средний городской этаж (50250 тыс. человек) пульсирует по сезонам года слабее (рисунок 4).

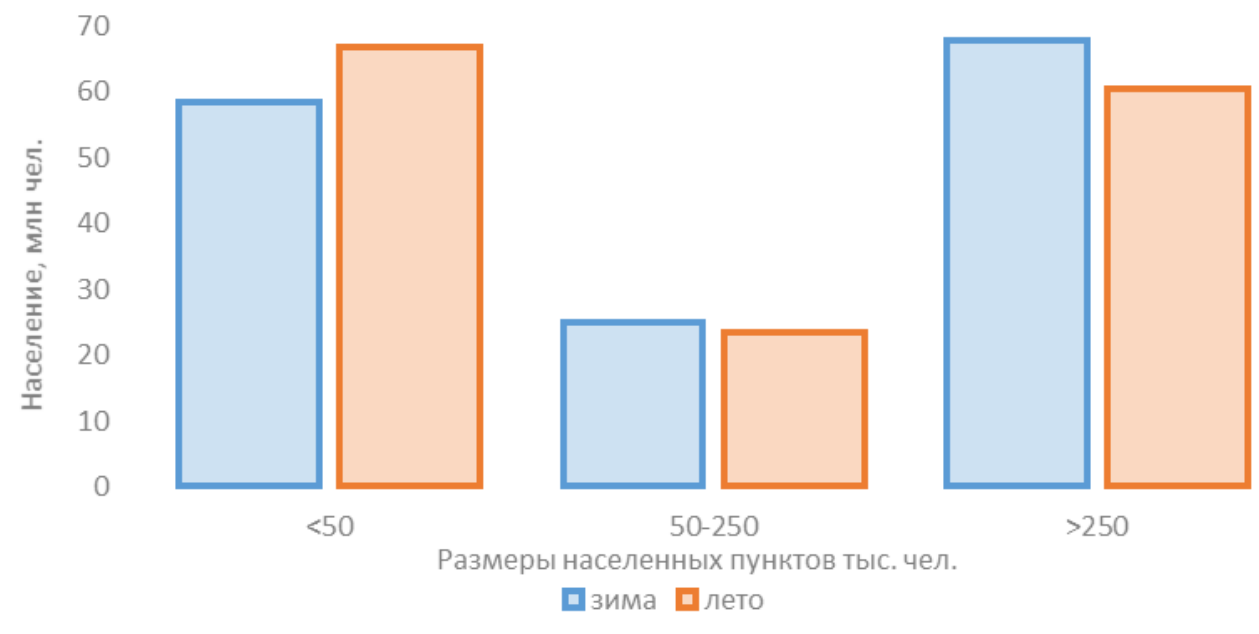

\section{Рисунок 4. Наличное население (млн) трех основных классов населенных мест (тыс.) в средний зимний и летний дни 2010 г.}

Источник: оценка автора.

Недельные ритмы, накладываясь на сезонные, усиливают эффект пульсации. Так, в зимний рабочий день в Москве можно насчитать 14 млн человек, а летом в выходной - 9 млн, т.е. на 5 млн меньше. Их плотность в центре столицы, где локализовано свыше трети ее рабочих мест, в будний зимний день превышает 40 тыс. человек на 1 км² $^{2}$ а погожим летним воскресеньем она вчетверо ниже. Примерно двух-четырехкратные перепады отмечены в Подмосковье, особенно на окраинах [Махрова и др. 2012]. Там и в дачных районах ближних областей обитателей в летние выходные дни бывает на порядок больше, чем зимой в будни. 
Компактные пространственные формы СГК предоставляют свои сочетания покоя с движением, оседлости со странничеством (второе всегда лимитируют время и скорость, достаток, здоровье, просто интерес). В компромисс между ценностями «дороги» и «дома» немалый вклад вносит сочетание городского и сельского образов жизни, искомое людьми давно и так или иначе ими находимое. Прежде всего, это «связка» мест жительства, труда и отдыха либо смены занятий.

Ее предлагает континуум любого масштаба вплоть до международного и мирового, которые привлекают внимание многих авторов [Урри 2012]. Между тем, как было показано, интенсивность движения существенно выше при более умеренных дистанциях, т.е. в СГК меньших пространственных масштабов. Если для СГК ранга агломерации ключевой (по сути, образующий их ритм перемещения) - суточный, то для мегалополисов не менее важной представляются недельная и сезонная пульсация их населения. Впрочем, специфика континуальности проявляется в том, что это население не только их: оно часто, порой надолго и на значительный процент «заимствуется» из других мест, а также «ссужается» другим местам. Ни один пространственно очерченный, всегда лишь условно, континуум не изолирован от остальных и от СГК глобального уровня. Все проницаемы для потоков, для внешней по отношению к ним мобильности (иначе отпадает сама идея географически полимасштабной континуальности).

Сверхподвижных новых кочевников, людей типа «перекати-поле» (rolling stones, homo mobilis) можно найти в глобальном городе. Но его яркие представители, такие как менеджеры крупных корпораций и звезды шоу-бизнеса, живут не столько в одном городе или стране, сколько в международных отелях, офисах, аэропортах, на престижных курортах. Их немного; они, что называется, не делают погоды. Немного и тех, кто сломя голову бежит из города в глухомань, в экологическое поселение или, напротив, чурается ее, исповедуя крайний урбанизм. Большинству нужны не крайности, а доступное в данных условиях сочетание городской и сельской жизни. С ростом достатка, знаний, свободы передвижения люди становятся более взыскательными потребителями пространства [Смирнягин 2012]. Вот залог модернизации расселения и обитаемого пространства.

\section{ЗАКЛЮЧЕНИЕ}

В виде заключения с прикладным контекстом обозначим ряд проблем управления, включая территориальное, которому, надо признать, чужда и неудобна сама идея СГК, как и пространственно мобильного населения. Чиновник привык иметь дело с четкими рубежами, определяющими его полномочия. Многомиллионные потоки пассажиров и колебания людности не могут игнорировать прежде всего те, кто отвечает за транспорт, энерго- и водоснабжение. Сбои тут не редкость, что показала российская история с отменой и возвратом электричек. А, скажем, от дачников местные власти получают слишком мало налогов, зато вынуждены реагировать на сезонные нагрузки в сфере торговли и услуг, включая коммунальные. Опыт многих бесед убеждает, что их политика в этом отношении и в отношении трудового отхода, за редкими исключениями, негативна или пассивнобезразлична. 
Власти регионов и муниципалитетов, их планы, программы развития территорий не готовы считаться с градиентами вместо границ и с непостоянным в пространстве и во времени населением. Все основные показатели, задачи и нормативы рассчитаны на его постоянство, будь это всего лишь статистическая фикция. Кстати, трудно понять, как при этом многие стратегии регионального и локального развития ставят на туризм при его очевидной пространственно-временной «волатильности».

Для управленцев важен административный, а теперь чаще муниципальный статус территорий, даже не связанный с реалиями социально-экономического пространства. Оно устроено иначе и чутко реагирует на положение места в разномасштабных континуумах, на приливы-отливы населения и колебания хозяйственной активности. Весьма важен субъективный фактор, влияющий на позиционирование мест и регионов, на их образ и брендинг, притяжение или отталкивание мигрантов и капиталов. Так, М.С. Гунько [2015] пришла к выводу, что статус райцентра (город, поселок городского типа или село, округ или поселение) менее важен для развития района, а по сути СГК, чем неформальные отношения поселений, т.е. органов самоуправления и конкретных чиновников.

Особую проблему в России представляет историческая слабость коммунального начала вообще и межмуниципальной, межселенной координации в особенности. Именно этой слабостью иногда, чаще кулуарно, чем открыто, объясняют принимаемые выше по вертикали решения о слиянии, укрупнении, расширении территориальных единиц, включая столь громкое, как расширение Москвы до границ Калужской области, по сути перекроившее границы двух субъектов Федерации. При ином подходе (в духе зарубежных ассоциаций и союзов), полагают сторонники таких действий, насущные задачи развития утонули бы в согласованиях, конфликтах и протестах, не решающих проблем поселений и регионов, включая те, что не могут быть решены без участия соседей. Но если не пытаться решать их «снизу» через взаимодействие, то его навыки не появятся никогда. «Сверху», как известно, всего не разглядеть и не учесть.

Во всяком случае, наука не может игнорировать процессы и явления, меняющие территориальные структуры, даже когда эти изменения малозаметны со стороны и касаются не столько объектов, сколько отношений и связей между ними. Опыт таких исследований, как было показано, в России есть, хотя его носители порой не подозревали, что предметом их анализа был среди прочего СГК. Думается, что рано или поздно общество и власть предъявят спрос на это знание, без которого неизбежны ошибки и неадекватные решения.

\section{ЛИТЕРАТУРА}

Горнова Г.В. (2011). Антиномии города. Омск: Изд-во ОмГПУ. 220 с.

Гунько М.С. (2015). Взаимосвязи малых городов и сельских районов в Центральной России. Автореф. дисс. канд. геогр. наук. М. 26 с.

Гунько М.С., О.Б. Глезер (2015). Малые районные центры и окружающие территории в Центральной России в 1970-2010 гг.: динамика и распределение населения // Известия РАН. Серия география. №1: 42-52. 
Зайончковская Ж.А. (1991). Демографическая ситуация и расселение. М.: Наука. 132 с.

Лола А.М. (2005). Основы градоведения и теории города (в российской интепретации). М.: КомКнига. 344 с.

Махрова А.Г., Т.Г. Нефедова, А.И. Трейвиш (2012). Москва: мегаполис? агломерация? мегалополис? // Демоскоп Weekly. №517-518. URL: http://www.demoscope.ru/weekly/2012/0517/tema07.php (дата обращения: 10.02.2016).

Махрова А.Г., П.Л. Кириллов (2015). Сезонная пульсация расселения в Московской агломерации под влиянием дачной и трудовой маятниковой миграции: подходы к изучению и оценка // Региональные исследования. №1(47): 117-125.

Миронов В.Н. (1999). Социальная история России периода империи (XVIII - начало XX в.). В 2-х томах. СПб.: Дмитрий Буланин. 1114 с.

Население России 2013: двадцать первый ежегодный демографический доклад (2015) / Отв. ред. С.В. Захаров. М.: Изд. дом Высшей школы экономики. 428 с.

Нефедова Т.Г. (2003). Сельская Россия на перепутье. М.: Новое издательство. 190 с. - (2013). Большой, средний, малый город и село в России // География, градостроительство, архитектура: синтез наук и практик. Смоленск: Ойкумена: 171191.

Обследование населения по проблемам занятости (2013). М.: ФСГС. URL: http://www.gks.ru/bgd/regl/b13_30/Main.htm (дата обращения: 12.02.2015).

Пациорковский В.В. (2010). Сельско-городская Россия. М.: ИСЭПН РАН. 390 с.

Полян П. (2014). Территориальные структуры - урбанизация - расселение: теоретические подходы и методы изучения. М.: Новый Хронограф. 788 с.

Смирнягин Л.В. (2012). Место вместо местоположения? (О сдвигах в фундаментальных понятиях географии) // Географическое положение и территориальные структуры: памяти И.М. Маергойза. М.: Новый хронограф: 421-456.

Тикунов А.В. (2009). Интегральные показатели пространственных моделей развития стран мира. М.: Либроком. 248 с.

Ткаченко А.А., А.А. Фомкина (2012). Глубинка Центральной России: опыт формализованного выделения // Российская глубинка - модели и методы изучения. Сборник статей. М.: Эслан: 49-61.

(2014). Об агломерированном расселении // Разнообразие как фактор и условие территориального развития. Ч.І. М.: Эслан: 63-68.

Урри Дж.(2012). Социология за пределами обществ: виды мобильности для XXI столетия / Пер. с англ. М.: Изд. дом Высшей школы экономики. 335 с.

Филиппов А.Ф. (2008). Социология пространства. СПб.: Владимир Даль. 290 с.

Численность и миграции населения Российской Федерации в 2012 году (2013). М.: ФСГС. $142 \mathrm{c}$.

Cloke P.J. (1979). Key settlements in rural areas. London: Methuen. 274 p.

Dewey R. (1960). The rural-urban continuum: real but relatively unimportant // American Journal of Sociology. 66 (1): 60-66.

Gibbs J. (1963). The evolution of population concentration // Economic Geography. 39 (2): 119129. 
Howard E. (1902). Garden cities of to-morrow. 2nd edition. London: S. Sonnenschein \& Co., Ltd. $195 \mathrm{p}$.

Lynch K. (2005). Rural-urban interaction in the developing world. London - New York:

Routledge. 209 p.

Miner H. (1952). The folk-urban continuum // American Sociological Review. 17: 529-37.

NCHS urban-rural classification scheme for countries (2013). Centers for Disease Control and Prevention. URL: http://www.cdc.gov/nchs/data_access/urban_rural.htm (дата обращения: 20.02.2016).

Redfield R. (1930). Tepoztlán, a Mexican village: a study of folk life. Chicago: Univ. of Chicago Press. 247 p.

Rural-urban continuum codes (2013). US department of agriculture. URL: http://www.ers.usda.gov/data-products/rural-urban-continuum-codes/documentation.aspx (accessed: 15.05.2015)

Sorokin P., C. Zimmerman (1929). Principles of rural-urban sociology. New York: Holt. 652 p.

The urban-rural continuum. Migration and rural development: selected topics for teaching and research (1998) // FAO Economic and Social Development Paper. №3. Rome: FAO. Some considerations on specific aspects of migration. URL: http://www.fao.org/docrep/x1372t/x1372 t05.htm. 1998 (дата обращения: 20.02.2016).

World development report 2009: reshaping economic geography (2009). Washington, DC: The World Bank. 376 p.

Zelinsky W. (1971). The hypothesis of the mobility transition // Geographical Review. №6: 219249. 


\title{
THE RURAL-URBAN CONTINUUM: THE DESTINY OF THE NOTION AND ITS LINK TO THE SPATIAL MOBILITY OF POPULATION
}

\section{ANDREI TREIVISH ${ }^{1, *}$}

\begin{abstract}
The article deals with the evolution, schemes and application domains of the rural-urban continuum concept, with the spatial and, partly, historical variety of its specific forms (continuums, in the plural), and with their types and attributes. The idea is often defined by contradiction, opposing it to a town vs. country antinomy and a sharp separation, both spatial and social. It seems to the author that this concept is a synonym for a settlement system regarded as an uninterrupted field, which can have various urban-rural proportions and can be studied at different scales. A survey of rural-urban graphic schemes leads to the conclusion that the different versions are complementary, reflecting the evolutionary, multi-scale and gradual nature of the continuum. An analysis of the Western and Russian experience ends with an attempt at a typology of continuums in Russia's main regions. The degree of complexity and heterogeneity is increasing, from the semi-rural towards the inter-regional or mega-urban type, with interference of different continual fields. The level of the population's spatial mobility is shown by rough calculations for Moscow and Russia. This mobility makes settlement patterns both continuous and pulsating. In conclusion, some problems of administration, which finds it hard to adopt the very idea of a continuum, are briefly stated.
\end{abstract}

Key words: rural-urban continuum, local (folk-urban) continuum, settlement system, lifestyle, spatial mobility, agglomeration, megalopolis (mega-region).

\section{REFERENCES}

Chislennost' i migracii naseleniya Rossijskoj Federacii v 2012 godu [Population number and migration of the Russian Federation] (2013). Moscow: FSGS [Federal state statistics service]. $142 \mathrm{p}$.

Cloke P.J. (1979). Key settlements in rural areas. London: Methuen. 274 p.

Dewey R. (1960). The rural-urban continuum: real but relatively unimportant // American Journal of Sociology. 66 (1): 60-66.

Filippov A.F. (2008). Sociologiya prostranstva [Sociology of space]. St. Petersburg: Vladimir Dal'. 290 p.

Gibbs J. (1963). The evolution of population concentration // Economic Geography. 39 (2): 119129.

Gornova G.V (2011). Antinomii goroda [Antinomy of town]. Omsk: Izd-vo OmGPU [Omsk State Pedagogical University Publishers]. 220 p.

\footnotetext{
${ }^{1}$ InStitute of GEOGRAPHY, RUSSIAN ACADEMy OF SCIENCES (RUSSia).

* CORRESPONDENCE: trene12@yandex.ru

DATE RECEIVED: November 2015.
} 
Gunko M.S. (2015). Vzaimosvyazi malyx gorodov i sel'skix rajonov v Central'noj Rossii [The relationships between the small towns and rural areas in Central Russia]. Avtoref. diss. kand. geogr. nauk [Autoabstract of the candidate dissertation in geography]. Moscow. 26 p.

Gunko M.S., O.B. Glezer (2015). Malye rajonnye centry i okruzhayushhie territorii v Central'noj Rossii v 1970-2010 gg.: dinamika i raspredelenie naseleniya [Small rayon centres and their environs in Central Russia in 1970-2010: population dynamics and distribution] // Izvestiya RAN. Seriya geografiya [Geography series]. 1: 42-52.

Howard E. (1902). Garden cities of to-morrow. 2nd edition. London: S. Sonnenschein \& Co., Ltd. $195 \mathrm{p}$.

Lola A.M. (2005). Osnovy gradovedeniya i teorii goroda (v rossijskoj intepretacii) [The ABC of urban studies and theory]. Moscow: KomKniga. 344 p.

Lynch K. (2005). Rural-urban interaction in the developing world. London - New York: Routledge. 209 p.

Makhrova A. G., T. G. Nefedova, A.I. Treivish (2012). Moskva: megapolis? aglomeraciya? megalopolis? [Moscow: A magapolis? an agglomeration? a megalopolis?] // Demoscope Weekly. 517-518. URL: http://www.demoscope.ru/weekly/2012/0517/tema07.php (accessed: 10.02.2016).

Makhrova A.G., P.L. Kirillov (2015). Sezonnaya pul'saciya rasseleniya v Moskovskoj aglomeracii pod vliyaniem dachnoj i trudovoj mayatnikovoj migracii: podxody $\mathrm{k}$ izucheniyu i ocenka [The seasonal pulsation of settlement system in Mocow agglomeration influenced by second dwelling and labour commuting: approaches to the study and assessment] // Regional'nye issledovaniya [Regional Studies]. 1 (47): 117-125.

Miner H. (1952). The folk-urban continuum // American Sociological Review. 17: 529-37.

Mironov V.N. (1999). Social'naya istoriya Rossii perioda imperii (XVIII - nachalo XX v.). V 2$\mathrm{x}$ tomax [Social history of Russia during the empire period (the 18th - early 20th century). In 2 vol.]. St. Petersburg: Dmitrij Bulanin. 1114 p.

Naselenie Rossii 2013: dvadcat' pervyj ezhegodnyj demograficheskij doklad [Population of Russia 2013: the twenty first annual demographic report] (2015) / S.V. Zakharov, ed. Moscow: Izd. dom Vysshej shkoly e'konomiki. 428 p.

NCHS urban-rural classification scheme for countries (2013). Centers for Disease Control and Prevention. URL: http://www.cdc.gov/nchs/data_access/urban_rural.htm (дата обращения: 20.02.2016).

Nefedova T.G. (2003). Sel'skaya Rossiya na pereput'e [Rural Russia at a crossroads]. Moscow: Novoe izdatel'stvo.190 p.

(2013). Bol'shoj, srednij, malyj gorod i selo v Rossii [Large, medium-sized and small city and countryside in Russia] // Geografiya, gradostroitel'stvo, arxitektura: sintez nauk i praktik [Geography, urban construction, architecture: a synthesis of science and practice]. Smolensk: Ojkumena: 171-191.

Obsledovanie naseleniya po problemam zanyatosti [Population survey on problems of employment] (2013). Moscow: FSGS [Federal state statistics service ]. URL: http://www.gks.ru/bgd/regl/b13_30/Main.htm (accessed: 12.02.2015).

Paciorkovskij V.V. (2010). Sel'sko-gorodskaya Rossiya [Rural-urban Russia]. Moscow: ISE'PN RAN [Institute for Socioeconomic problems of Population]. 390 p. 
Polyan P. (2014). Territorial'nye struktury - urbanizaciya - rasselenie: teoreticheskie podxody i metody izucheniya [Territorial structures - urbanization - settlement: theorethical approaches and research methods]. Moscow: Novyj Xronograf. 788 p.

Redfield R. (1930). Tepoztlán, a Mexican village: a study of folk life. Chicago: Univ. of Chicago Press. 247 p.

Rural-urban continuum codes (2013). US department of agriculture. URL: http://www.ers.usda.gov/data-products/rural-urban-continuum-codes/documentation.aspx (accessed: 15.05.2015)

Smirnyagin L.V. (2012). Mesto vmesto mestopolozheniya? (O sdvigax v fundamental'nyx ponyatiyax geografii) [Locus instead of Location? (About some fundamental shifts in ideas of geography)]// Geograficheskoe polozhenie i territorial'nye struktury: pamyati I.M. Maergojza [Geographical position and territorial structures: in memory of I.M. Maergoiz]. Moscow: Novyj Xronograf 421-456.

Sorokin P., C. Zimmerman (1929). Principles of rural-urban sociology. New York: Holt. 652 p.

The urban-rural continuum. Migration and rural development: selected topics for teaching and research (1998) // FAO Economic and Social Development Paper. №3. Rome: FAO. Some considerations on specific aspects of migration. URL: http://www.fao.org/docrep/x1372t/x1372 t05.htm. 1998 (accessed: 20.02.2016 ).

Tikunov A.V. (2009). Integral'nye pokazateli prostranstvennyx modelej razvitiya stran mira [Integral indicators of spatial development models for the countries of the world]. Moscow: Librokom. 248 p.

Tkachenko A.A., A.A. Fomkina (2012). Glubinka Central'noj Rossii: opyt formalizovannogo vydeleniya [Backwoods of Central Russia: an experience of a formalized selection] // Rossijskaya glubinka — modeli i metody izucheniya. Sbornik statej [The Russia's hinterland — models and research methods. Collection of articles]. Moscow: E'slan 49-61.

(2014). Ob aglomerirovannom rasselenii [On agglomerated settlement]// Raznoobrazie kak faktor i uslovie territorial'nogo razvitiya [Diversity as a factor and condition of territorial development]. Ch. 1. [P. 1]. Moscow: E'slan: 63-68.

Urry J. (2012). Sociologiya za predelami obshhestv: vidy mobil'nosti dlya XXI stoletiya [Sociology beyond societies: mobilities for the twenty-first century]. Moscow: Izd. dom Vysshej shkoly e'konomiki. 335 p.

World development eport 2009: reshaping economic geography (2009). Washington, DC: The World Bank. 376 p.

Zaionchkovskaya Zh.A. (1991). Demograficheskaya situaciya i rasselenie [Demographic situation and settlement]. Moscow: Nauka. 132 p.

Zelinsky W. (1971). The hypothesis of the mobility transition // Geographical Review. №6: 219249. 